\title{
Case Based Reasoning Untuk Diagnosis Penyakit Demam Berdarah
}

\author{
Rabiah Adawiyah \\ ${ }^{1}$ Sistem Informasi Universitas Sembilanbelas November Kolaka \\ ${ }^{1}$ Kolaka, Indonesia \\ E-mail: ${ }^{1}$ rabiah.heru@ gmail.com
}

Abstrak - Virus Dengue merupakan virus penyebab penyakit demam dengue (DD), demam berdarah dengue (DBD) dan sindrom syok dengue (SSD). Penyakit ini termasuk dalam status KLB di Rumah Sakit Benyamin Guluh Kab. Kolaka. Masuknya penyakit ini dalam status KLB maka terdapat banyak

kasus/pasien yang ditangani setiap tahunnya bahkan setiap bulannya. Gejala seorang pasien terdiagnosis penyakit demam berdarah ini cenderung mirip. Case Based Reasoning (CBR) merupakan salah satu metode yang mampu melakukan penalaran atau memecahkan permasalahan berdasarkan kasus yang telah ada sebagai solusi masalah baru. Sistem yang dibangun dalam penelitian ini adalah sistem CBR untuk melakukan diagnosis terhadap penyakit Demam Berdarah. Proses diagnosis yaitu memasukkan permasalahan baru dibandingkan dengan kasus lama lalu dihitung nilai similaritasnya.

Dalam penelitian ini metode Nearest neighbor digunakan untuk proses similarity. Pengujian menggunakan 54 kasus sebagai data uji secara acak dan 85 kasus digunakan sebagai basis kasus. Hasil yg diperoleh yaitu nilai sensitifitas $98.14 \%$ dan akurasi sistem $99.25 \%$.

Kata Kunci-Case Based Reasoning, Demam Berdarah, Nearest Neighbor

\section{Pendahuluan}

Infeksi dengue merupakan suatu penyakit infeksi akibat virus dengue melalui nyamuk genus Aedes terutama A.aegypti dan A.albopictus [1]. Infeksi dengue bisa bersifat asimptomatik atau berupa demam yang tak jelas, berupa demam dengue (DD), demam berdarah dengue (DBD) sampai dengan kebocoran plasma yang berakibat syok (SSD). Infeksi dengue kadang tidak bergejala tetapi kalau ada gejala tampak dari gambaran klinis yang sangat bervariasi mulai dari demam ringan sampai gangguan sistem syaraf pusat dan syok yang mengancam jiwa [2]. Penyakit ini tidak hanya sering menimbulkan kejadian luar biasa (KLB) khususnya untuk Rumah Sakit Benyamin Guluh Kab. Kolaka. Penyakit ini juga menimbulkan dampak buruk sosial maupun ekonomi karena menimbulkan kepanikan dalam keluarga, kematian anggota keluarga, dan berkurangnya usia harapan penduduk.

Perkembangan ilmu pengetahuan dan teknologi informasi saat ini dapat diberdayakan untuk membantu mengerjakan pekerjaan manusia. Pengkajian dan penelitian untuk mewujudkan hal itu dilakukan dengan meniru sistem kecerdasan manusia untuk menghasilkan sebuah sistem komputer 
yang mampu berfikir dan bekerja seperti seorang manusia. Bagian ilmu komputer yang mempelajari hal tersebut dikenal dengan istilah kecerdasan buatan (Artificial Intelligence).

Pada umumnya penyelesaian masalah yang dihadapi dapat dilakukan dengan melihat pengalamanpengalaman yang telah dimiliki, ataupun berdasarkan pengalaman dari orang lain. Hal inilah yang menjadi dasar sehingga menghasilkan suatu metode baru yang dikenal dengan penalaran berbasis kasus (case based reasoning). Representasi pengetahuan (knowledge representasi) dari sebuah basis kasus reasoning adalah berupa kumpulan kasus (case base) yang telah terjadi sebelumnya. Dalam penyelesaian suatu permasalahan CBR menggunakan solusi dari kasus terdahulu yang mirip dengan kasus saat ini. Proses mencari kedekatan antara masalah baru dengan kasus lama dapat menggunakan berbagai macam metode, dimana metode ini mempengaruhi keberhasilan dari kerja CBR dalam menentukan kasus lama yang paling mirip dengan masalah baru (target case). Salah satu metode yang digunakan dalam penelitian ini untuk menghitung kemiripan (similarity) adalah Nearest neighbor.

Beberapa penelitian yang menggunakan CBR [3] untuk diagnosis penyakit THT. Penyusunan indeks pada basis kasus didasarkan pada kelas dan subkelas penyakit THT dengan menggunakan jaringan syaraf tiruan model backpropagation, sedangkan pengukuran similarity menggunakan metode Nearest neighbor dengan cosine coefficient, [4] membahas tentang penggunaan self-organizing maps (SOM) dan learning vector quantization (LVQ) pada proses Indexing kasus untuk penalaran berbasis kasus, penelitian [5] pengembangan sistem cerdas menggunakan penalaran berbasis kasus (CBR) untuk mendiagnosis penyakit akibat virus eksantema. Dalam penelitian ini jenis-jenis penyakit yang dihasilkan oleh virus eksantema diantaranya: cacar air, campak, valiora. Teknik retrieval yang digunakan adalah probabilitas bayes. [6] mengembangkan prototipe pendukung keputusan klinis untuk diagnosis dan penatalaksanaan demam berdarah dengue menggunakan menghasilkan tingkat validitas kinerja sistemnya sebesar $100 \%$.Dari beberapa penelitian tersebut menunjukkan hasil bahwa CBR menggunakan teknik indexing menghasilkan kinerja sistem lebih cepat.

Dengan menggunakan metode CBR yang memiliki keunggulan salah satunya yaitu mengurangi akuisisi pengetahuan dengan menghilangkan kebutuhan untuk ekstrak model atau kumpulan dari aturan-aturan, seperti yang diperlukan dalam model/sistem yang berbasis aturan. Akuisisi pengetahuan pada CBR terdapat pada kumpulan pengalaman/kasus-kasus sebelumnya [7] dengan menggunakan similarity Nearest neighborn diharapkan dapat melakukan diagnosis penyakit demam berdarah dengan lebih cepat dan lebih baik.

\section{Metode Penelitian}

\section{A. Deskripsi Sistem}

Sistem CBR untuk diagnosis penyakit demam berdarah ini dimulai dengan melakukan 2 proses yaitu 
proses pertama memasukkan data kedalam basis kasus yang diperoleh dari rekam medis yang telah diindex berdasarkan jenis penyakit, dengan menggunakan kode P1 untuk penyakit DD, P21 untuk penyakit DBD Grade1, P22 untuk penyakit DBD Grade2, P23 untuk penyakit DBD Grade3 dan P3 untuk penyakit SSD. Kemudian proses kedua yaitu melakukan proses pengujian data dengan memasukkan data target case dengan menggunakan metode Nearest neighbor untuk menemukan kasus termirip dengan solusinya berupa saran tindakan medis terhadap kasus yang telah terindex.

Proses retrieval untuk menemukan hasil diagnosis dan solusi pada target case dilakukan dengan memasukkan data pasien, gejala, hasil lab dan hasil pemeriksaan untuk dihitung nilai similaritasnya dengan kasus tersimpan dalam basis kasus. Setiap fitur memiliki bobot dengan nilai tertentu. Nilai bobot diperoleh dari pakar. Kesamaan masing-masing fitur dikalikan dengan bobot menggunakan rumus similarity lokal pada persamaan (1) untuk data numerik dan persamaan (2) untuk data simbolik, selanjutnya dihitung secara keseluruhan menggunakan rumus similarity global Nearest neighbor yang telah dimodifikasi [8] sesuai dengan persamaan (3). Apabila nilai similarity tersebut lebih kecil dari nilai threshold yang telah ditentukan yaitu 0.6, maka solusi dari kasus tersebut harus direvisi terlebih dahulu oleh pakar dan disimpan ke basis kasus setelah proses revisi dilakukan. Dan jika hasil similarity diatas treshold maka dilakukanlah proses reuse yaitu sistem menghasilkan keluaran (output) berupa jenis penyakit yang paling mirip dengan masalah baru tersebut serta solusi berupa saran tindakan medis yang harus dilakukan. Nilai treshold diperoleh dengan melakukan pengujian terhadap data-data testing yang ada. Hasil perhitungan pada masing-masing kasus diurutkan dari nilai tertinggi ke terendah. Nilai yang tertinggi adalah kasus yang paling mirip dengan masalah baru. Nilai kemiripan antara 0 sampai dengan 1. Jika nilai kemiripan $=1$, maka kasus tersebut samapersis sehingga tidak perlu disimpan dalam basis kasus karena kasus seperti itu sdh ada, dan sebaliknya semakin kecil nilai similaritasnya maka kasus tersebut semakin tidak mirip dan jika berada diatas nilai treshold maka kasus tersebut dapat disimpan dalam basis kasus.

$$
\begin{aligned}
& f(s, t)=1-\frac{|s-t|}{R} \\
& f(s, t)=\left\{\begin{array}{l}
1 \text { ijkas:t } \\
0 \text { lainngad dimana s,t } t \in\{\text { benar, salah }\}
\end{array}\right. \\
& \operatorname{Sim}(S, T)=\left(\frac{\sum_{i=1}^{n} f\left(S_{i j} T_{i}\right) * w_{i}}{\sum_{i=1}^{n} w_{i}}\right) * P(S) * \frac{J(S i, T i)}{J(T i)}
\end{aligned}
$$

\section{B. Representasi Kasus}

Kasus direpresentasikan dalam bentuk frame berupa kumpulan fitur-fitur yang menjadi ciri kasus tersebut dan solusi untuk menangani kasus tersebut. Fitur-fitur tersebut bisa didapat dari akuisisi pengetahuan seperti melakukan wawancara dengan pakar, mengambil referensi dari buku-buku yang terkait masalah penelitian serta teknik pengumpulan data lainnya. Kumpulan kasus yang telah diperoleh 
Jurnal INTENSIF, Vol.1, No.1, Februari 2017

ISSN: $2549-6824$

dari catatan rekam medis pasien di Rumah Sakit Benyamin Guluh Kab.Kolaka. Data yang diperoleh selanjutnya dikonsultasikan dengan pakar untuk kemudian ditentukan data-data mana saja yang dapat dijadikan sebagai fitur kasus dan kemudian di cocokkan juga dengan referensi yang peneliti gunakan dari WHO. Beberapa fitur yang teridentifikasi yaitu: usia, jenis kelamin, kelurahan (tempat tinggal), gejala, hasil laboratorium (darah) dan hasil pemeriksaan yang digunakan untuk menentukan solusi berupa saran tindakan medis yang dapat dilakukan oleh paramedis. Representasi kasus dalam bentuk frame sesuai dengan Tabel 1.

TABEL I. REPRESENTASI KASUS DALAM Bentuk FRAME

\begin{tabular}{|c|c|}
\hline Fitur & Nilai \\
\hline No. Kasus & : K0128 \\
\hline Kode Pasien & : A070 \\
\hline Nama Pasien & : Aulia Amanda \\
\hline Umur & $: 4$ \\
\hline Jenis Kelamin & : Wanita \\
\hline Kelurahan & : Sabilambo \\
\hline Gejala & $: \mathrm{G} 1, \mathrm{G} 3, \mathrm{G} 6$ \\
\hline \multicolumn{2}{|l|}{ Hasil Lab } \\
\hline Leukosit (WBC) & $: 5.56$ \\
\hline Eritrosit (RBC) & $: 4.86$ \\
\hline Hemoglobin (HGB) & $: 10$ \\
\hline Hematokrit (HCT) & $: 32.4$ \\
\hline Trombosit (PLT) & $: 64$ \\
\hline \multicolumn{2}{|l|}{ Hasil Pemeriksaan } \\
\hline Denyut nadi (ND) & $: 110$ \\
\hline Pernapasan (PS) & $: 28$ \\
\hline Suhu Badan (SB) & $: 39$ \\
\hline Tekanan Darah (TS) & $: 120 / 70$ \\
\hline Hasil Indexing & $\ldots \ldots \ldots \ldots \ldots \ldots \ldots$ \\
\hline Solusi & (....................... \\
\hline
\end{tabular}

C. Proses Retrieval untuk Diagnosis Penyakit Demam Berdarah

Proses retrieval user bertindak sebagai pemakai memasukkan data target case atau masalah baru dengan memasukkan biodata pasien, hasil lab dan gejala-gejala yang dialami oleh pasien. Kemudian dilakukan proses similarity menggunakan Nearest Neighbor dengan menambahkan fitur hasil pemeriksaan pada kasus yang telah terindex untuk menemukan kasus termirip dengan solusi berupa saran tindakan medis sesuai pada Gambar 1 
Jurnal INTENSIF, Vol.1, No.1, Februari 2017

ISSN: 2549-6824

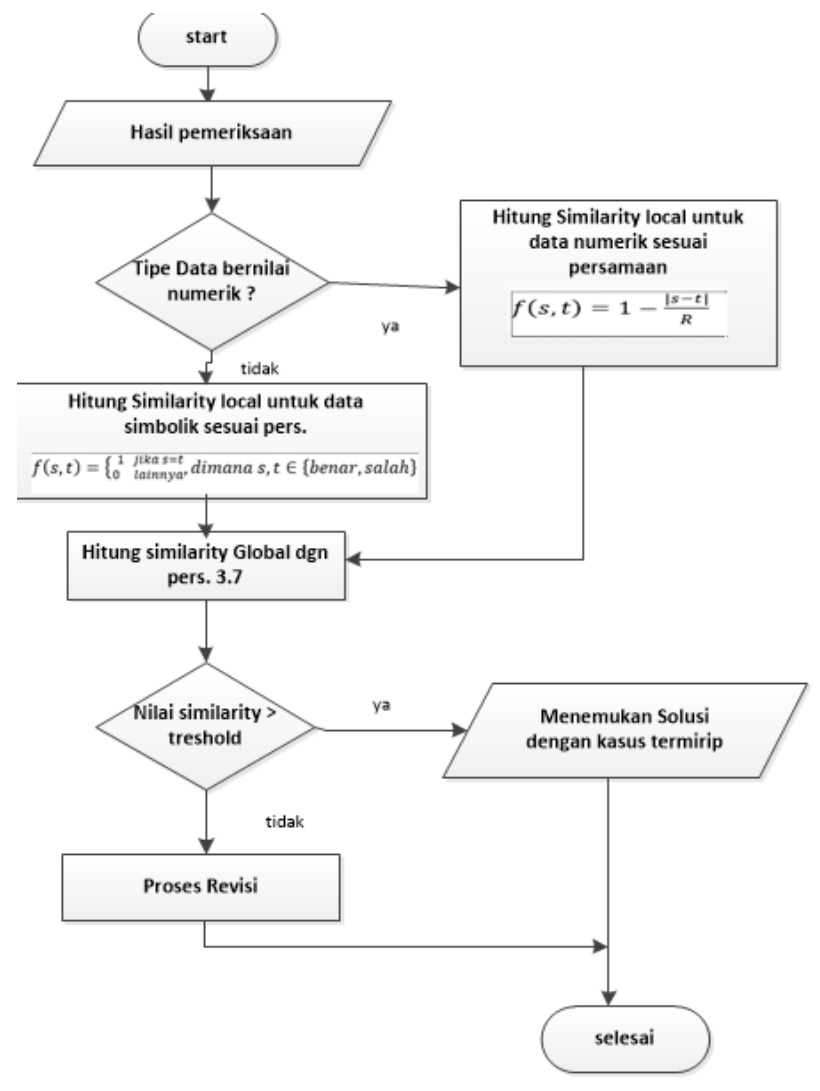

GAMBAR I. FLOWCHART PROSES RETRIEVAL UNTUK DIAGNOSIS PENYAKIT DEMAM BERDARAH

Berikut proses perhitungan similaritas untuk target case (target case) dengan kasus yang ada dalam basis kasus (source case) sesuai dengan Tabel 2.

TABEL II. CONTOH KASUS PROSES Sim ILARITAS

\begin{tabular}{|c|c|c|c|c|c|}
\hline \multirow[t]{3}{*}{ Data kasus } & \multicolumn{4}{|c|}{ Source case (S) } & \multirow{2}{*}{$\begin{array}{l}\text { Target } \\
\text { case }(\mathrm{T})\end{array}$} \\
\hline & K001 & & K002 & & \\
\hline & Nilai & Bobot & Nilai & Bobot & \\
\hline Umur & 13 & 7 & 13 & 7 & 13 \\
\hline Jenis kelamin & Wanita & 6 & Wanita & 6 & Wanita \\
\hline Kelurahan & Watuliandu & 8 & Lamokato & 8 & Lamokato \\
\hline Gejala & G1 & 10 & G1 & 10 & G1 \\
\hline Gejala & G3 & 7 & G4 & 7 & G4 \\
\hline Gejala & G4 & 8 & G6 & 7 & G6 \\
\hline Gejala & G9 & 7 & G9 & 8 & G9 \\
\hline Hasil Lab (WBC) & $2.99=R=1$ & 9 & $4=R=2$ & 9 & $4=R=2$ \\
\hline Hasil Lab (RBC) & $5.99=\mathrm{T}=3$ & 6 & $5.71=\mathrm{T}=3$ & 6 & $5.6=\mathrm{T}=3$ \\
\hline Hasil Lab (HGB) & $13.3=\mathrm{N}=2$ & 7 & $15=\mathrm{N}=2$ & 7 & $14=\mathrm{N}=2$ \\
\hline Hasil Lab (HCT) & $47.81=\mathrm{T}=3$ & 8 & $15.2=\mathrm{N}=2$ & 8 & $45=\mathrm{N}=2$ \\
\hline Hasil Lab (PLT) & $112=A b n=2$ & 10 & $49=R=3$ & 10 & $50=R=3$ \\
\hline Hasil Pemeriksaan (ND) & $84=2$ & 6 & $88=2$ & 6 & $90=2$ \\
\hline Hasil Pemeriksaan (PS) & $22=3$ & 8 & $20=2$ & 8 & $18=2$ \\
\hline Hasil Pemeriksaan (TS) & $110 / 80=2$ & 6 & $100 / 70=2$ & 6 & $100 / 70=2$ \\
\hline Hasil Pemeriksaan (SB) & $36.5=2$ & 9 & $37.5=3$ & 9 & $37.7=3$ \\
\hline Keyakinan Pakar & $100 \%$ & & $85 \%$ & & \\
\hline Diagnosis penyakit & $\mathrm{DD}$ & & $\begin{array}{c}\text { DBD } \\
\text { Grade } 3\end{array}$ & & $-\ldots \ldots \ldots \ldots$ \\
\hline Solusi & SA03 & & $\mathrm{SA} 03$ & & \\
\hline
\end{tabular}

1. Similaritas target case dengan source case (K001)

- Similaritas Lokal :

a.kedekatan fitur umur:

$$
f(S i, T i) \quad=1-\operatorname{abs}\left(\frac{13}{65}\right)=1-(0.2)=0.8
$$


b. kedekatan fitur jenis kelamin $=1$, karena jenis kelamin pada source case dan target case sama.

c.kedekatan fitur kelurahan $=0$, karena kelurahan pada source case dan target case tidak sama.

d.Kedekatan fitur gejala, G1,G4 dan G9 = 1 karena gejala tersebut berada pada target case dan source case, sedangkan G3 dan G6 = 0 karena G3 hanya ada di source case dan tidak ada ditarget case begitupun sebaliknya untuk G6.

e.Kedekatan fitur hasil lab

- Leukosit ( WBC)

$$
f(S i, T i) \quad=1-a b s\left(\frac{2.99-4}{14}\right)=1-\frac{1.01}{14}=0.92
$$

- Eritrosit (RBC)

$$
f(S i, T i)=1-a b s\left(\frac{5.99-5.71}{10}\right)=1-\frac{0.39}{10}=0.961
$$

- Hemoglobin (HGB)

$$
f(S i, T i)=1-a b s\left(\frac{13.3-14}{20}\right)=1-\frac{0.7}{20}=0.965
$$

- Hematokrit (HCT)

$$
f(S i, T i)=1-a b s\left(\frac{47.81-45}{60}\right)=1-\frac{2.81}{60}=0.95
$$

- Trombosit (PLT)

$$
f(S i, T i)=1-a b s\left(\frac{112-50}{160}\right)=1-\frac{62}{160}=0.61
$$

f.Kedekatan Pemeriksaan

- Suhu Badan (SB)

$$
f(S i, T i) \quad=1-a b s\left(\frac{2-2}{7}\right)=1-\frac{0}{7}=1
$$

- Pernapasan(PS)

$$
f(S i, T i) \quad=1-a b s\left(\frac{3-2}{3}\right)=1-\frac{1}{3}=0.66
$$

- Tensi(TS)

$$
f(S i, T i) \quad=1-a b s\left(\frac{2-2}{5}\right)=1-\frac{0}{5}=1
$$

- Denyut Nadi (ND)

$$
f(S i, T i) \quad=1-a b s\left(\frac{2-2}{3}\right)=1-\frac{0}{3}=1
$$

- Similaritas Global

$$
\begin{gathered}
(0.75 * 7)+(1 * 6)+(0 * 8)+(1 * 10)+(1 * 7)+ \\
(0 * 2)+(1 * 6)+(0.92 * 9)+(0.96 * 6)+(0.96 * 7)+ \\
\operatorname{Sim}(S, T)=\frac{(0.95 * 8)+(0.61 * 10)+(1 * 6)+(0.66 * 8)+(1 * 6)+(1 * 9)}{(7+6+8+10+7+2+6+9+6+7+8+10+6+} \\
8+6+9) \\
\operatorname{Sim}(S, T)=\frac{96.95}{115}=0.84 * 100 \% \frac{14}{16} \\
\operatorname{Sim}(S, T)=72.27 \%
\end{gathered}
$$


Jurnal INTENSIF, Vol.1, No.1, Februari 2017

ISSN: 2549-6824

2. Similaritas target case dengan source case (K002)

- Similaritas Lokal :

a.kedekatan fitur umur:

$$
f(S i, T i)=1-a b s\left(\frac{3-3}{4}\right)=1-\frac{0}{4}=1
$$

b. kedekatan fitur jenis kelamin $=1$, karena jenis kelamin pada source case dan target case sama.

c.kedekatan fitur kelurahan $=1$, karena kelurahan pada source case dan target case sama.

d. Kedekatan fitur gejala, G1,G4,G6 dan G9 = 1 karena gejala pada target case tersebut berada source case

e.Kedekatan fitur hasil lab

- Leukosit (WBC)

$$
f(S i, T i) \quad=1-a b s\left(\frac{4-4}{14}\right)=1-\frac{\mathrm{o}}{14}=1
$$

- Eritrosit (RBC)

$$
f(S i, T i) \quad=1-a b s\left(\frac{5.71-5.71}{10}\right)=1-\frac{0}{10}=1
$$

- Hemoglobin (HGB)

$$
f(S i, T i)=1-a b s\left(\frac{15.4-14}{20}\right)=1-\frac{1.4}{20}=0.93
$$

- Hematokrit (HCT)

$$
f(S i, T i)=1-a b s\left(\frac{15.2-45}{60}\right)=1-\frac{29.8}{60}=0.50
$$

- Trombosit (PLT)

$$
f(S i, T i)=1-a b s\left(\frac{49-50}{160}\right)=1-\frac{1}{160}=0.99
$$

f.Kedekatan Pemeriksaan

- Suhu Badan (SB)

$$
f(S i, T i) \quad=1-a b s\left(\frac{2-2}{7}\right)=1-\frac{0}{7}=1
$$

- Pernapasan(PS)

$$
f(S i, T i)=1-a b s\left(\frac{2-2}{3}\right)=1-\frac{0}{3}=1
$$

- $\quad$ Tensi (TS)

$$
f(S i, T i) \quad=1-a b s\left(\frac{2-2}{5}\right)=1-\frac{0}{5}=1
$$

- Denyut Nadi (ND)

$$
f(S i, T i)=1-a b s\left(\frac{2-2}{3}\right)=1-\frac{0}{3}=1
$$


Jurnal INTENSIF, Vol.1, No.1, Februari 2017

ISSN: 2549-6824

- Similaritas Global

$$
\begin{gathered}
(1 * 7)+(1 * 6)+(1 * 8)+(1 * 10)+(1 * 7)+ \\
(1 * 2)+(1 * 6)+(1 * 9)+(1 * 6)+(0.93 * 7)+ \\
\operatorname{Sim}(S, T)=\frac{(0.50 * 8)+(0.99 * 10)+(1 * 6)+(1 * 8)+(1 * 6)+(1 * 9)}{(7+6+8+10+7+2+6+9+6+7+8+10+6+} \\
8+6+9) \\
\operatorname{Sim}(S, T)=\frac{110.47}{115}=0.96 * 85 \% \frac{16}{16} \\
\operatorname{Sim}(S, T)=81.65 \%
\end{gathered}
$$

Berdasarkan perhitungan similaritas target case terhadap source case (K001 dan K002) dengan hasil K001 adalah $72.27 \%$ dan K002 adalah $81.65 \%$ maka nilai similaritas pada K002 lebih besar dibandingkan nilai similaritas K001, dapat disimpulkan bahwa source case (K002) merupakan kasus yang paling mirip dengan target case menghasilkan diagnosis DBD Grade 3 dengan Solusi SA03 sesuai dengan diagnosis dan solusi K002.

D. Proses Pengujian Sistem

Pengujian dilakukan dengan mengambil sampel secara acak sebanyak 54 kasus sebagai data uji. Pengujian dilakukan dengan menghitung nilai sensitivitas dan mengetahui nilai akurasi dari tes diagnostik [9]. Akurasi yaitu tingkat kedekatan pengukuran kuantitas terhadap nilai yang sebenarnya. Pengujian dilakukan untuk mengenali sistem secara benar dikenal dengan sensivisitas menggunakan persamaan (4) dan pengujian yang dilakukan untuk menghitung tingkat kesamaan atau kedekatan hasil diagnosis antara data uji dan data yang sebenarnya dikenal dengan istilah akurasi sistem menggunakan persamaan (5).

$$
\begin{gathered}
\text { Sensitivitas }=\frac{T P}{T P+F N} * 100 \\
\text { Akurasi }=\frac{T P+T N}{T P+T N+F P+F N} * 100
\end{gathered}
$$

\section{Hasil \& PEMBahasan}

\section{A. Pengujian Sistem}

Data uji kasus adalah data rekam medis pasien yang diperoleh dari bagian Rekam Medis pada RS. Beyamin Guluh Kab. Kolaka. Digunakan sebanyak 54 kasus sebagai data uji dari jumlah data penelitian yaitu 139 kasus. Pengujian dilakukan dengan memasukkan data uji satu persatu dan hasil diagnosis sistem dari data uji dikatakan benar jika memiliki hasil yang mirip dengan hasil diagnosis dari pakar dan memiliki hasil similaritas > threshold serta dihitung sensitivitas dan akurasinya untuk menghasilkan sebuah kesimpulan terbaik. 
Skenario pengujian dilakukan terhadap 54 kasus sebagai data uji, menggunakan nearest neigbord sebagai proses similarity untuk memperoleh kasus yang termirip. Proses pengujian ini dilakukan untuk menguji tingkat kebenaran sistem dalam mendiagnosis penyakit (DD, DBD dan SSD). Hasil pengujian menunjukkan bahwa terdapat 53 kasus yangterdiagnosis benar dan terdapat 1 data uji yang berada dibawah nilai < treshold yang artinya bahwa hasil diagnosis oleh sistem berbeda dengan data riil (diagnosis dari pakar) yaitu terletak pada data uji ke-44 dengan nilai similarity 0.56 data riil adalah DD sedangkan sistem menghasilkan diagnosis SSD.

\section{TAB EL III. HASIL PENGUJIAN Sistem DENGAN Diagnosis BENAR}

\begin{tabular}{l|c|c|}
\multirow{2}{*}{ Jenis Penyakit } & \multirow{2}{*}{ Jumlah Data Uji } & \multicolumn{2}{|c}{\begin{tabular}{c} 
Jumlah Diagn \\
\cline { 3 - 3 }
\end{tabular}} & $\begin{array}{c}\text { Tanpa Indexing } \\
\text { (Nearest Neighbor) }\end{array}$ \\
\hline DD & 5 & 4 \\
\hline DBD Grade 1 & 5 & 5 \\
\hline DBD Grade 2 & 7 & 7 \\
\hline DBD Grade 3 & 6 & 6 \\
\hline SSD & 31 & 31 \\
\hline Jumlah & 54 & 53 \\
\hline
\end{tabular}

\section{B. Evaluasi Sistem}

Evaluasi hasil pengujian sistem dilakukan dengan menghitung nilai sensitivitas dan akurasi. Evaluasi dilakukan untuk mengetahui apakah hasil sistem yang telah dibangun layak untuk diterapkan dalam mendiagnosis penyakit demam berdarah. Menghitung nilai sensitivitas dan akurasi berdasarkan confusion matrix dari skenario pengujian yang dilakukan. Tabel 4 merupakan Tabel confusion matrix

\section{TABEL IV. HASIL PERHITUNGAN CONFUSION MATRIX}

\begin{tabular}{l|c|c|c|c|c|} 
Jenis Diagnosis & Data uji & TP & TN & FP & FN \\
\hline DD & 5 & 4 & 49 & 1 & 0 \\
\hline & & $4 / 5$ & $49 / 49$ & $1 / 5$ & $0 / 49$ \\
\hline DBD Grade 1 & 5 & 5 & 49 & 0 & 0 \\
\hline & & $5 / 5$ & $49 / 49$ & $0 / 5$ & $0 / 49$ \\
\hline DBD Grade 2 & 7 & 7 & 47 & 0 & 0 \\
\hline DBD Grade 3 & 6 & $7 / 7$ & $47 / 47$ & $0 / 7$ & $4 / 47$ \\
\hline & & $6 / 6$ & 48 & 0 & 0 \\
\hline SSD & 31 & 31 & 22 & 0 & 1 \\
\hline & & $31 / 31$ & $22 / 23$ & $1 / 31$ & $1 / 23$ \\
\hline & & & & & \\
\hline Jumlah & 54 & 53 & 215 & 1 & 1 \\
\hline
\end{tabular}

$$
\begin{aligned}
& \text { Sensitivitas }=\frac{53}{53+1} * 100 \%=98.14 \% \\
& \text { akurasi }=\frac{53+215}{53+215+1+1} * 100 \%=99.25 \%
\end{aligned}
$$

Hasil pengujian sistem dilakukan dengan menghitung nilai sensitivitas dan akurasi dengan nilai yang diperoleh yaitu sensitivitas $=98.14 \%$ dan nilai akurasi sistem sebesar $99.25 \%$ sehingga dapat dikatakan bahwa sistem CBR yang dibangun dapat mendiagnosis penyakit demam berdarah dengan baik dan benar. 
C. Tampilan Interface

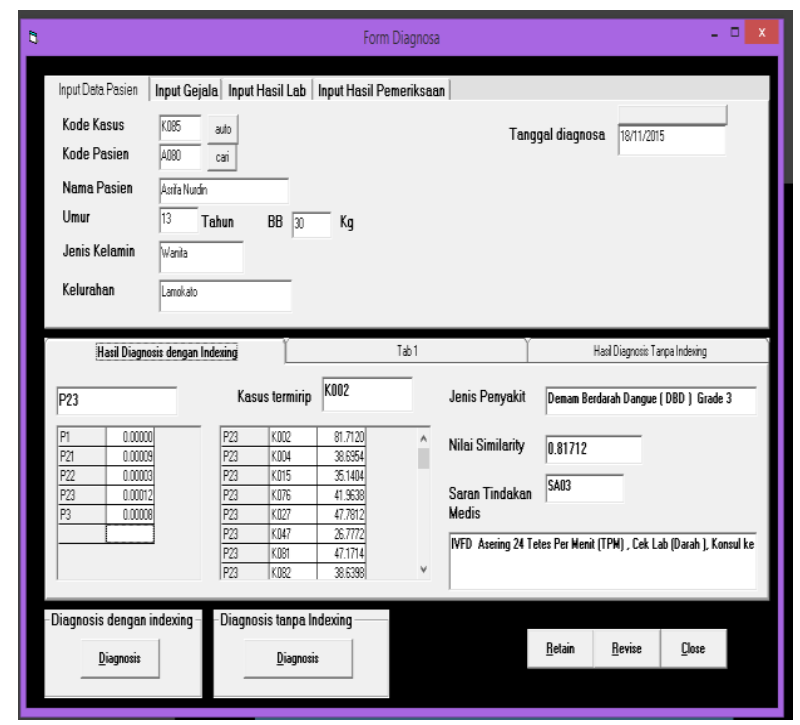

\section{GAMBAR II. TAMPILAN SISTEM CBR UNTUK DIAGNOSIS PENYAKIT DEMAM BERDARAH}

Pada gambar 2 dapat menunjukkan diagnosis penyakit demam berdasar jenis apa yang diderita oleh seorang pasien ( kasus baru ) serta solusi yang dihasilkan.

\section{KESIMPULAN \& SARAN}

Hasil pengujian yang telah dilakukan terhadap 54 data uji, menunjukkan bahwa sistem mampu mengenali penyakit tersebut dengan menggunakan nearest neighbor dengan nilai sensitivitas $98.14 \%$ dan akurasi sistem $99.25 \%$. Berdasarkan hasil pengujian yang diperoleh maka dapat dikatakan bahwa sistem CBR yang dibangun dapat mendiagnosis penyakit akibat virus dengue dengan baik dan benar. Dapat digunakan teknik Indexing dengan metode lain sehingga hasil yang diperoleh nantinya dapat dibandingkan mana yang penggunaanya paling optimal. Pada penelitian selanjutnya, sistem dapat dibangun dalam bentuk website atau aplikasi mobile sehingga pengguna dapat lebih leluasa mengakses sistem kapan saja dan dimana saja.

\section{Daftar Pustaka}

[1] Hadinegoro, S.R.H, Soegijanto S, Wuryadi S, Suroso T., 2004, Tatalaksana Demam Berdarah Dengue di Indonesia. Departemen Kesehatan Direktorat Jenderal Pemberantasan Penyakit Menular dan Penyehatan Lingkungan, Jakarta.

[2] Gubler, D.J., 1998. Dengue and Dengue Haemorrhagic Fever. Clin Microbiol Rev, 11(3): 480496.

[3] Pearl, J., 1991, Probalistic Reasonin In Intelligent System, Morgan Kaufmann Publisher, Inc. 
Jurnal INTENSIF, Vol.1, No.1, Februari 2017

ISSN: $2549-6824$

[4] Rismawan, T., 2012, Case Based Reasoning untuk Diagnosis Penyakit THT, Tesis, S2 Ilmu Komputer UGM, Yogyakarta.

[5] Kim Kyung, dkk, 2001, The Cluster - Indexing Method for Case Based Reasoning using Self Organization Map and Learning Vector Quantization For Bond Rating Cases, Expert System With Application 21, 147-156.

[6] Aribowo, A.S., 2010, Pengembangan Sistem Cerdas Menggunakan Penalaran Berbasis Kasus (Case Based Reasoning) untuk Diagnosis Penyakit Akibat Virus Eksantema, Jurnal Telematika, Vol 7, No.1, Halaman 11-22, ISSN 1829-667X.

[7] Suharyanto., 2011, Pengembangan Prototipe Sistem Pendukung Keputusan Klinis untuk Diagnosis dan Penatalaksanaan Demam Berdarah Dengue, Tesis, S2 Fakultas Kedokteran UGM, Yogyakarta.

[8] Pal, K. S., dan Shiu, K.C.S., 2004, Foundations of Soft Basis kasus Reasoning, A John Wiley \& Son, Inc., Publication, New Jersey.

[9] Mancasari, U.A., 2012, Sistem Pakar Menggunakan Penalaran Berbasis Kasus untuk Mendiagnosis Penyakit Syaraf pada Anak, Skripsi, S1 Ilmu Komputer UGM, Yogyakarta.

[10] Akobeng, A.K., 2007, Understanding Diagnostic Tests 1 : Sensitivity, Specificity and Predictive Value, Acta Pædiatrica, Vol. 96 No. 3, ISSN: 1651-2227, Halaman 338-341. 